\title{
PYOCIN-SENSITIVITY TESTING AS A MEANS OF TYPING PSEUDOMONAS AERUGINOSA
}

\author{
J. R. TAGG ${ }^{1}$ AND ROSE MUSHIN \\ School of Microbiology, University of Melbourne, Victoria, Australia
}

AW ARENESS of the importance of tracing the source of infections with Pseudomonas aeruginosa, and of studying the distribution of this organism in hospital wards and the routes by which it may spread in hospitals, have led to the development of several schemes for typing it. To date, the most successful and widely applied procedures have been based upon the detection of pyocin (aeruginocin) production by these organisms (Darrell and Wahba, 1964; Gillies and Govan, 1966), to which we shall refer as "pyocin-typing" methods.

The epidemiological value of any typing procedure depends largely upon the relative frequency of the various types encountered, and is greater with rare than with common types. Unfortunately, several of the types defined by Gillies and Govan's method are rather common; for example, we found that members of their types 1, 3 and 10 amounted to 29,20 and 12 per cent. respectively of 2411 strains of $P$. aeruginosa examined (Tagg and Mushin, 1971). This problem is alleviated somewhat by the use of additional indicator strains. Govan and Gillies (1969) were able to recognise eight sub-types of their type 1 by the use of five additional indicator strains. Similarly, we used two additional indicator strains, which enabled us to subdivide the common types 1,10 and 5 , and also reduced the frequency of apparently untypable strains (Tagg and Mushin).

Various other procedures have been tested as possible auxiliary methods for the "fingerprinting" of strains of the more commonly encountered pyocin types, including antibiogram determinations, bacteriophage typing and serotyping (Deighton, Tagg and Mushin, 1971; Tagg and Mushin). Other schemes have been devised for the typing of isolates of $P$. aeruginosa according to their sensitivity to different pyocin preparations (Osman, 1965; Farmer and Herman, 1969). These procedures are essentially similar to the colicin-sensitivity test first used by Hamon (1961) for the typing of strains of Escherichia coli. The present paper includes an examination of pyocin-sensitivity testing as a possible epidemiological tool for the subdivision of members of some of the more commonly encountered pyocin types.

\section{MATERIALS AND METHODS \\ Strains of Pseudomonas aeruginosa}

The indicator bacteria for pyocin typing consisted of the eight strains (labelled $I_{1}$ to $I_{8}$ ) used by Gillies and Govan, and two additional indicator strains $I_{A}$ and $I_{B}$, described previously

Received 23 Feb. 1973; accepted 20 Apr. 1973.

1 Present address: Departments of Pediatrics and Microbiology, University of Minnesota, Minneapolis, Minnesota 55455.

J. MED. MICROBIOL.-VOL. 6 (1973) 
(Tagg and Mushin). The five pyocin producer strains (called $\mathbf{P}_{\mathbf{1}}, \mathbf{P}_{\mathbf{3}}, \mathbf{P}_{\mathbf{5}}, \mathbf{P}_{\mathbf{9}}$ and $\mathbf{P}_{\mathbf{1 0}}$ ) used for pyocin-sensitivity testing were obtained from $\operatorname{Dr} R$. R. Gillies and were of pyocin subtypes $1_{A}, 3_{A B}, 5_{A}, 9_{A}$ and $10_{A}$. The type numbers are those of Gillies and Govan, and the sub-type designations are shown by letters in the inferior position, as follows: $A$ indicates inhibition of strain $I_{A}, B$ of strain $I_{B}, A B$ of both these strains, and $O$ of neither. The strains of $\boldsymbol{P}$. aeruginosa typed in the present investigation had been obtained from clinical specimens and were selected from the strains used previously (Tagg and Mushin). The procedures adopted for the isolation, species characterisation, pyocin typing and storage of these strains have already been described (Tagg and Mushin).

\section{Induction of pyocin production}

Cultures in the logarithmic phase of growth were obtained by inoculating $0.1 \mathrm{ml}$ of an $18-\mathrm{hr}\left(32^{\circ} \mathrm{C}\right)$ Nutrient-Broth (Oxoid) culture of the test strain into $10 \mathrm{ml}$ of fresh nutrient broth, followed by incubation with constant shaking for $3-4 \mathrm{hr}$ at $32^{\circ} \mathrm{C}$. Mitomycin C (Nutritional Biochemicals Co., Cleveland, Ohio) was then added to give a final concentration of $1 \mu \mathrm{g}$ per $\mathrm{ml}$, and the cultures were reincubated with shaking for $4 \mathrm{hr}$ at $32^{\circ} \mathrm{C}$. The cells were deposited by centrifugation at $4000 \mathrm{~g}$ for $20 \mathrm{~min}$. and the supernate was sterilised by filtration before testing for pyocin activity.

\section{Assay of pyocin}

Cultures of the indicator strains in the logarithmic growth-phase were mixed in $0.05-\mathrm{ml}$ quantities with $2-\mathrm{ml}$ portions of nutrient agar that had been melted and cooled to $50^{\circ} \mathrm{C}$. The seeded agar was poured to form an overlayer on nutrient agar (5-mm thick) in 100-mm plates. After the surface of the medium had been dried for $30 \mathrm{~min}$. at $37^{\circ} \mathrm{C}, 0.05-\mathrm{ml}$ drops of two-fold dilutions in nutrient broth of the pyocin solutions were deposited on appropriately labelled sectors of the plates by means of calibrated Pasteur pipettes. The drops were allowed to become absorbed completely into the medium, and the plates were then inverted and incubated at $32^{\circ} \mathrm{C}$ for $18 \mathrm{hr}$. Degrees of inhibition of the growth of the indicator cultures were recorded as follows: $++t=$ complete inhibition; $++=$ single colonies in the zone of inhibition; $t=$ slightly inhibited growth; $-=$ no inhibition. The pyocin titre was arbitrarily defined as the reciprocal of the highest dilution of the test preparation to produce ++ or greater inhibition. Bacteriophage activity was recognised by the appearance of discrete plaques with increasing dilutions and the presence of these was confirmed by serial propagation on the sensitive indicator strain (Adams, 1959).

\section{Pyocin-sensitivity testing}

Pyocin-containing solutions, obtained by induction with mitomycin $C$ of strains $P_{1}, P_{3}$, $P_{5}, P_{9}$ and $P_{10}$, were diluted with nutrient broth to give titres of $c .8$ when tested against strain $I_{5}$, which was sensitive to pyocins produced by each of these strains. The specificity of the preparations was checked by assaying the activity against the complete set of 10 indicator strains. Two different procedures were used.

For the first, overlayer nutrient-agar cultures of the test strains were prepared as for pyocin assay, and the pyocin-containing solutions were deposited, in $0.05-\mathrm{ml}$ drops, on appropriate sectors of the medium. A control preparation consisting of nutrient broth with $1 \mu \mathrm{g}$ per $\mathrm{ml}$ of mitomycin $\mathrm{C}$ was included in each experiment. Assessment of the inhibitory patterns followed incubation at $32^{\circ} \mathrm{C}$ for $18 \mathrm{hr}$. A strain was considered to be sensitive to a particular pyocin only if an inhibition reading of ++ or greater was recorded. Pyocin-sensitivity patterns were designated by listing the type designations corresponding to the pyocin preparations to which the strain under test was sensitive, separated by oblique lines. Thus, sensitivity to pyocin preparations from strains $1_{A}, 3_{A B}$ and $10_{A}$ was recorded as $1_{A} / 3_{A B} / 10_{A}$.

The second method was based on a modification of the punch-hole procedure of antibiotic testing and has been described in detail previously (Tagg and McGiven, 1971). Glass petri dishes were filled with nutrient agar to a thickness of $7 \mathrm{~mm}$, and six holes were punched in it by means of a cork borer of 4-mm diameter. After sealing the base of each hole with one drop 
$(0.05 \mathrm{ml})$ of nutrient agar, $0.01 \mathrm{ml}$ of each pyocin preparation and of the mitomycin $\mathrm{C}$ contro was added to its appropriate well and allowed to diffuse into the medium for $1 \mathrm{hr}$ at $37^{\circ} \mathrm{C}$. The medium was then inverted, exposing the bottom surface of the gel, which was dried at $37^{\circ} \mathrm{C}$ for 1-2 $\mathrm{hr}$ and then inoculated by flooding with $2 \mathrm{ml}$ of a logarithmic-growth-phase culture of the test strain and removing the excess fluid with the aid of a Pasteur pipette. The plates were then dried and incubated at $32^{\circ} \mathrm{C}$ for $18 \mathrm{hr}$ before being examined for evidence of pyocin activity, which was recorded as above.

\section{RESULTS}

The overlayer method of pyocin-sensitivity testing was examined as a possible means of subdividing 101 strains of $P$. aeruginosa belonging to the commonly

TABLE

Distribution of patterns of pyocin sensitivity among strains belonging to various pyocin subtypes

\begin{tabular}{|c|c|c|c|c|c|c|c|c|c|}
\hline \multirow{3}{*}{$\begin{array}{l}\text { Pyocin-sensitivity } \\
\text { pattern }\end{array}$} & \multicolumn{8}{|c|}{ Number of strains } & \multirow{3}{*}{$\begin{array}{l}\text { Total } \\
\text { number } \\
\text { examined }\end{array}$} \\
\hline & \multicolumn{7}{|c|}{$\begin{array}{l}\text { with the stated sensitivity to pyocins among members } \\
\text { of pyocin sub-type }\end{array}$} & \multirow{2}{*}{ untypable } & \\
\hline & $1_{A}$ & $1_{A B}$ & 10 & $\mathbf{3}_{\mathbf{A B}}$ & 30 & $10_{\mathrm{A}}$ & $10_{A B}$ & & \\
\hline $\begin{array}{c}1_{\mathrm{A}} \\
3_{\mathrm{AB}} \\
5_{\mathrm{A}} \\
9_{\mathrm{A}} \\
3_{\mathrm{AB}} / 5_{\mathrm{A}} \\
1_{\mathrm{A}} / 10_{\mathrm{A}} \\
1_{\mathrm{A}} / 5_{\mathrm{A}} / 10_{\mathrm{A}} \\
1_{\mathrm{A}} / 3_{\mathrm{AB}} / 10_{\mathrm{A}} \\
1_{\mathrm{A}} / 3_{\mathrm{AB}} / 5_{\mathrm{A}} / 10_{\mathrm{A}} \\
1_{\mathrm{A}} / 3_{\mathrm{AB}} / 5_{\mathrm{A}} / 9_{\mathrm{A}} / 10_{\mathrm{A}} \\
\text { Untypable } \\
\text { Any }\end{array}$ & $\begin{array}{l}0 \\
3 \\
9 \\
0 \\
2 \\
0 \\
0 \\
0 \\
0 \\
0 \\
28 \\
42\end{array}$ & $\begin{array}{r}0 \\
0 \\
18 \\
1 \\
1 \\
4 \\
2 \\
0 \\
0 \\
0 \\
8 \\
34\end{array}$ & $\begin{array}{l}0 \\
0 \\
0 \\
0 \\
0 \\
0 \\
0 \\
0 \\
8 \\
0 \\
0 \\
8\end{array}$ & $\begin{array}{l}2 \\
0 \\
0 \\
0 \\
0 \\
0 \\
3 \\
0 \\
0 \\
0 \\
1 \\
6\end{array}$ & $\begin{array}{l}0 \\
0 \\
0 \\
0 \\
0 \\
0 \\
0 \\
1 \\
0 \\
0 \\
0 \\
1\end{array}$ & $\begin{array}{l}0 \\
0 \\
7 \\
0 \\
0 \\
0 \\
0 \\
0 \\
0 \\
0 \\
2 \\
9\end{array}$ & $\begin{array}{l}0 \\
0 \\
0 \\
0 \\
0 \\
0 \\
0 \\
0 \\
0 \\
1 \\
0 \\
1\end{array}$ & $\begin{array}{l}0 \\
0 \\
2 \\
0 \\
0 \\
0 \\
0 \\
0 \\
1 \\
2 \\
6 \\
11\end{array}$ & $\begin{array}{r}2 \\
3 \\
36 \\
1 \\
3 \\
4 \\
5 \\
1 \\
9 \\
3 \\
45 \\
112\end{array}$ \\
\hline
\end{tabular}

encountered pyocin-types 1,3 and 10, and eleven other strains found to be untypable by the conventional pyocin-typing procedure. Five of the "untypable" strains were sensitive to pyocins and, in all, 11 distinct patterns of pyocin sensitivity were differentiated (the table). Of the 112 strains tested, 45 (40 per cent.) were resistant to all the pyocin preparations. Arrangement of the organisms into their particular pyocin subtypes in this table provides a clear demonstration of the phenomenon of pyocin immunity - the highly specific resistance of pyocin-producing strains to the killing action of pyocin of the corresponding type. Thus, pyocin preparations of type $1_{\mathrm{A}}$ inhibited the growth of six strains of pyocin-type $1_{A B}$ and eight of type $1_{O}$, but all 42 strains of type $1_{\mathrm{A}}$ appeared to be immune to it. Similarly, the only pyocin-type 3 strain sensitive to pyocin $3_{\mathrm{AB}}$ preparations was a member of the uncommon subtype $3_{\mathrm{O}}$, and the only type 10 strain sensitive to pyocin $10_{\mathrm{A}}$ preparations belonged to pyocin-type $10_{\mathrm{AB}}$. Comparison of the modified punch-hole method with the conventional overlayer technique indicated that the same sensitivity patterns were obtained by both. 
The stability of the pyocin preparations on storage was an important consideration. Since the titres seemed to decrease slowly at $4^{\circ} \mathrm{C}$ (particularly that of the pyocin of the subtype $5_{A}$ strain) fresh preparations were generally made at intervals of 2-3 wk. Controls of the potency and specificity of the pyocin suspensions were included in each experiment.

Repeated testing of strains with various patterns of pyocin sensitivity after storage in nutrient broth for $6 \mathrm{mth}$ at $4^{\circ} \mathrm{C}$ showed no apparent change in these. Similarly, there was no apparent alteration in the patterns after up to $12 \mathrm{mth}$ of weekly subculture of the 12 pyocin-indicator strains on nutrient agar.

The in-vivo constancy of pyocin-sensitivity patterns was assessed according to several of the criteria used previously to test the validity of a pyocin-typing procedure (Deighton et al., Tagg and Mushin). The patterns of several strains of the same pyocin type isolated from different sites in the same patient indicated that the organisms were consistent, whilst strains of the same pyocin types isolated from different patients often had distinct patterns of pyocin sensitivity. The examination of strains from two incidents of suspected cross-infection caused by organisms of the unclassifiable pyocin types, $\mathrm{UC}_{1}$ and $\mathrm{UC}_{\mathrm{A}}$ provided further evidence of the usefulness of pyocin-sensitivity tests. Previous studies had shown that, whilst the $\mathrm{UC}_{\mathrm{A}}$ strains could be subdivided according to differences in antibiogram, phage-typing pattern and serotype, all of the $\mathrm{UC}_{1}$ strains consistently gave the same reaction when tested by each of these procedures (Deighton et al.; Tagg and Mushin). The result of pyocin-sensitivity tests supported the previous findings; all of the $\mathrm{UC}_{1}$ strains isolated during the outbreak had the same pattern of sensitivity whilst the $\mathrm{UC}_{\mathrm{A}}$ strains had several different patterns.

\section{DisCUSSION}

Determination of the pattern of sensitivity to pyocins proved to be a useful epidemiological tool for the subdivision of strains of $P$. aeruginosa belonging to some of the more common pyocin types. The reliability of the technique was confirmed both epidemiologically and by the repeated testing of strains after prolonged storage or subculture. There was no indication of any variation in the sensitivity of strains to pyocin, either in vivo or in vitro.

Although 40 per cent. of the strains tested were untypable by the present procedure, the inclusion of additional pyocin preparations might be expected to reduce this figure substantially. Only five different pyocin preparations were used in the current test, but Farmer and Herman (1969) have demonstrated the "fingerprinting" of 100 per cent. of 157 strains of $P$. aeruginosa according to their responses to a set of 24 different phage-pyocin lysates.

Strains that produce pyocin of a particular subtype were shown to be immune to the killing action of pyocin of the same subtype. This property of specific immunity to the corresponding bacteriocin is a feature of most Gram-negative bacteriocinogenic organisms, although far less marked among Gram-positive species (Tagg, Read and McGiven, 1971).

A new method of testing for sensitivity to pyocins, based upon the punch-hole procedure of antibiotic assay, was used in the present study and compared with 
a conventional overlayer technique. Although similar results were obtained by use of each procedure, the punch-hole test seems to offer definite advantages in the reading and interpretation of results. By the use of this technique it is possible to compare directly the degree of pyocin sensitivity of different strains by measurement of the diameter of the inhibitory zones surrounding the corresponding wells. Furthermore, inhibitory activity due to bacteriophages present in the pyocin preparations may be excluded from consideration because, under the conditions of the test, bacteriophages are unable to diffuse through the agar gel to make contact with the test lawn culture.

\section{SUMMARY}

Pyocin-sensitivity testing is a useful adjunct to a routine pyocin-typing scheme for Pseudomonas aeruginosa, permitting the subdivision of many groups of strains that belong to the same pyocin type, and also reducing the frequency of untypable strains.

\section{REFERENCES}

AdAMs, M. H. 1959. Bacteriophages. New York.

DARrell, J. H., AND WAHBA, A. H. 1964. Pyocine-typing of hospital strains of Pseudomonas pyocyanea. J. Clin. Path., 17, 236.

Deighton, M. A., TAGG, J. R., AND Mushin, R. 1971. Epidemiology of Pseudomonas aeruginosa strains in a study of cross-infection in a children's hospital. Med. J. Aust., 1, 892.

FARMER, J. J., III, AND HERMAN, L. G. 1969. Epidemiological fingerprinting of Pseudomonas aeruginosa by the production of and sensitivity to pyocin and bacteriophage. Appl. Microbiol., 18, 670.

Gillres, R. R., AND Govan, J. R. W. 1966. Typing of Pseudomonas pyocyanea by pyocine production. J. Path. Bact., 91, 339.

Govan, J. R. W., AND Gillies, R. R. 1969. Further studies on the pyocine typing of Pseudomonas pyocyanea. J. Med. Microbiol., 2, 17.

Hamon, Y. 1961. Colicines et lysotypie. Zentbl. Bakt. ParasitKde, 1 Abt. Orig., 181, 456.

Osman, M. A. M. 1965. Pyocine typing of Pseudomonas aeruginosa. J. Clin. Path., 18, 200.

TAGG, J. R., AND Mushin, R. 1971. Epidemiology of Pseudomonas aeruginosa infection in hospitals. 1. Pyocine typing of Ps. aeruginosa. Med. J. Aust., 1, 847.

TAGG, J. R., AND MCGIVEN, A. R. 1971. Assay system for bacteriocins. Appl. Microbiol., 21, 943.

TAGG, J. R., READ, R. S. D., AND MCGiven, A. R. 1971. Bacteriocine production by group A streptococci. Pathology, 3, 277. 